ARTIKEL

Filsafat Politik Nurcholish Madjid

Muhammad Saleh Tajuddin

Kedaulatan Rakyat dalam Pemikiran Filsafat

Politik Montesquieu

Fajrul Ilmy Darussalam \& Andi Batara Indra

$189-204$

Politik Multikulturalisme: Sebuah Gerakan Keadilan

dan Kesetaraan

Muhaemin Latif

$205-229$

Kompetisi, Kompromi dan Coalition Agreement: Berebut

Kursi Wakil Gubernur DKI Jakarta di Tengah

Kontestasi Pemilihan Presiden 2019

Mahpudin \& Fransisca Mega Lestari

$230-259$

Kegagalan Keterlibatan Politik: Dari Kesenjangan Digital

Menuju Kesenjangan Demokrasi

Fairuz Arta Abhipraya \& Bambang Eka Cahya Widodo

Mobilisasi Massa Kemenangan Kolom Kosong Pada Pemilihan Walikota Makassar Tahun 2018

Gustiana Kambo

Kinerja Komisi Pemilihan Umum Kota Makassar dalam

Melindungi Hak Pilih Warga di Tengah

Pandemi COVID-19

Dyahwanti Sulistyowati, Muhammad, Sukri \& Ariana

Isu Pemekaran Wilayah Sebagai Komoditas Politik Dalam Masyarakat

To Pulo di Kepulauan Selayar

Dwi Indriani \& Sudarmono

Penanganan Konflik Melalui Keamanan di Kalimantan Barat 


\title{
KINERJA KOMISI PEMILIHAN UMUM KOTA MAKASSAR DALAM MELINDUNGI HAK PILIH WARGA DI TENGAH PANDEMI COVID-19
}

\author{
Dyahwanti Sulistyowati ${ }^{1}$, Muhammad ${ }^{2}$, Sukri $^{3}$ \& Ariana $^{4}$ \\ Program Sudi Ilmu Politik Universitas Hasanuddin ${ }^{1-4}$ \\ Email: raihanahdyah@gmail.com ${ }^{1}$, alhamid.muhammad41@gmail.com², \\ sukripolitik@gmail.com ${ }^{3}$, ana.yun@yahoo.com ${ }^{4}$
}

\begin{abstract}
Abstrak
Salah satu tahapan yang selalu menjadi masalah pada saat pemilihan umum adalah tahapan pemutakhiran data pemilih. Pemutahkhiran data merupakan tahapan yang sangat krusial karena berkaitan dengan hak pilih warga. Artikel ini berusaha menjawab bagaimana kinerja KPU Kota Makassar dalam melindungi hak pilih warga di tengah pandemi COVID-19?. Metode penelitian yang digunakan adalah penelitian deskriptif dengan pendekatan kualitatif. Hasil penelitian menunjukkan bahwa KPU Kota Makassar telah melakukan tugasnya dalam proses pemutakhiran data pemilih. Daftar Pemilih Tetap Pilwalkot 2020 menurun disebabkan banyaknya warga Makassar yang tidak berada ditempat pada saat pencocokan dan penelitian (coklit). Namun sosialisasi terus dilakukan oleh KPU Kota Makassar baik secara konvensional maupun secara modern melalui media sosial. Selain itu, kerjasama dengan Dinas Kependudukan dan Catatan Sipil terus dilakukan agar masyarakat yang belum memiliki KTP-el melakukan perekaman sehingga pada saat pemilihan dapat menggunakan hak pilihnya.
\end{abstract}

\section{Kata Kunci:}

Kinerja KPU, Pemutakhiran Data, Hak Pilih

\begin{abstract}
A common problem that is usually found in the election process is updating the voters' data. It is a very crucial stage because it is related to the citizens' voting rights. This article looks at how the performance of the General Election Commission of Makassar city (KPU Kota Makassar) in protecting citizens' voting rights during COVID-19 crisis. The research used descriptive research with a qualitative approach. The results of the study indicate that the commission had carried out its duties in the process of updating voters' data. The list of permanent voters for the 2020 in Makassar mayoral election decreased due to the large number of Makassar residents who were not staying in Makassar during the time of matching and research procedure (coklit). However, socialization continued to be organized bot in conventional and a modern platform through social media. In addition, collaboration with the Department of Population and Civil Registration, KPU Kota Makassar managed to update the data. Hence, people who do not have electronic identification card (E-KTP) can used their voting rights.
\end{abstract}

Keywords:

Performance, Updating Data, Voting Right 


\section{Pendahuluan}

Pandemi COVID-19 merupakan bencana global yang berdampak diberbagai bidang. Salah satu dampak politik yang dirasakan yaitu terkait penyelenggaraan pemilihan umum (pemilu) di setiap negara. Ada beberapa negara yang tetap melaksanakan pemilu tetapi beberapa negara yang menyelenggarakan pemilu terpaksa merubah jadwal pelaksanaan karena dikhawatirkan berakibat buruk terhadap kesehatan manusia. Salah satu negara yang melaksanakan pemilu yaitu Indonesia. Indonesia melaksanakan pemilihan kepala daerah dan wakil kepala daerah (Pilkada) di sejumlah daerah yang terdiri dari 9 provinsi, 224 kabupaten serta 37 kota. Pelaksanaan Pilkada di tahun 2020 awalnya dijadwalkan pada tanggal 23 September 2020 kemudian diundur pelaksanaannya menjadi tanggal 9 Desember 2020.

Pelaksanaan Pilkada di tengah pandemi COVID-19 menuai pro-kontra. Di sisi lain, Pilkada merupakan saluran bagi rakyat untuk memilih pemimpin yang layak demi terwujudnya kehidupan demokrasi di Indonesia. Namun di lain sisi, Pilkada di tengah pandemi COVID-19 akan membahayakan kesehatan dan keselamatan rakyat. Namun demikian, Pilkada tetap dilaksanakan walau terdapat sejumlah catatan, seperti isu protokol kesehatan, perlindungan hak pilih warga dan carut marut pendataan pemilih. Dua hal terakhir disebutkan adalah persoalan klasik yang sering terulang, problem data statistik pemilih secara kuantitatif selalu mengalami perubahan setiap menjelang pemilu. Penambahan jumlah data pemilih yang berbeda antar lembaga negara, yakni Badan Pusat Statistik, Kementerian Dalam Negeri dan Komisi Pemilihan Umum (KPU) semakin memperunyam pelaksanaan Pilkada. Hal ini disebabkan karena ketiadaan data pemilih yang terintegrasi secara akurat.

Sementara itu, banyaknya pemilih yang kehilangan hak pilih dan menjadikann Komisi Pemilihan Umum (KPU) sebagai sasaran kritik karena dianggap gagal melaksanakan perannya. KPU dinilai gagal karena tidak jeli pada proses pemutakhiran data pemilih yang sifatnya door to door. Padahal, untuk pemutakhiran data, KPU juga telah membuka pelaporan baik langsung maupun tidak langsung (online) kepada masyarakat, hanya saja masih terdapat masyarakat yang acuh dan malas untuk melakukan validasi data. Di lain sisi, masyarakat yang tidak dapat mengakses informasi dari KPU berkontribusi hilangnya sebagaian hak pilih masyarakat. Contoh kasus 
misalnya, di Kota Makassar pada saat pemilu 2019 salah satu warga kehilangan hak pilih karena alasan kesibukan bekerja di luar kota. Pada pemilu sebelumnya selalu memberikan hak pilihnya maka pemilih tersebut tidak pernah mengecek apakah sudah terdaftar atau tidak pada portal lindungihakpilihmu.kpu.go.id. Namun pada saat ingin memilih di TPS yang berbeda ternyata pemilih tersebut tidak terdaftar pada Daftar Pemilih Tetap (DPT) sehingga pemilih tersebut tidak dapat menggunakan hak pilihnya.

Di masa pandemi ini, proses pencocokan dan penelitian (coklit) berbeda dibanding situasi normal. Banyaknya masyarakat yang takut ketika menerima tamu di rumah mereka, menyebabkan pendataann atau coklit agak terhambat. Sehingga DPT untuk Pilwalkot 2020 di Kota Makassar mengalami penurunan dibandingkan DPT pada Pilwalkot 2018 dan Pileg 2019. Perbandingan jumlah DPT yakni DPT Pilwalkot 2018 yakni 990.836; DPT Pileg 2019 yakni 967.590; dan Pilwalkot 2020 yakni 901.087.

Melihat terjadinya penurunan jumlah DPT di kota Makassar disertai adanya salah satu kasus pemilih yang dicoret hak pilihnya pada tahun 2019, maka menjadi sebuah pertanyaan apakah metode dan cara coklit di masa pandemi ini membuat banyak pemilih tidak terdata atau ada faktor-faktor lain yang menyebabkan terjadinya penurunan jumlah pemilih di Kota Makassar ataukah dengan turunnya jumlah pemilih, kualitas data pemilih yang dihasilkan lebih baik dibandingkan dengan jumlah pemilih yang banyak, maka penulis kemudian merumuskan pertanyaan penelitian sebagai berikut: bagaimana kinerja KPU Kota Makassar dalam melindungi hak pilih warga di tengah pandemi COVID-19?.

\section{Tinjauan Pustaka}

Studi tentang perlindungan hak pilih telah banyak dilakukan, misalnya artikel Felani Ahmad Cerdas dan Hernadi Afandi tentang Jaminan Perlindungan Hak Pilih dan Kewajiban Negara Melindungi Hak Pilih Warga Negara dalam Konstitusi: Kajian Kritis Pemilu Serentak 2019. ${ }^{1}$ Cerdas dan Afandi menguraikan alasan konstitusional yang menjadi dasar bagi negara untuk memberikan jaminan perlindungan kepada warga negara untuk dapat menggunakan hak pilih dalam pemilu. Sejalan dengan itu, Himawan Estu Bagijo dalam artikelnya Daftar Pemilih Tetap Dan Perlindungan Hak Pilih: Kajian

${ }^{1}$ Felani Ahmad Cerdas \& Hernadi Afandi, "Jaminan Perlindungan Hak Pilih dan Kewajiban Negara Melindungi Hak Pilih Warga Negara dalam Konstitusi: Kajian Kritis Pemilu Serentak 2019” dalam SASI, Vol. 25, No. 1 (2019), h. 72-83. 
Perundang-Undangan Dan Keputusan Mahkamah Konstitusi, ${ }^{2}$ mengungkapkan bahwa hak pilih warga negara perlu dilindungi. Apalagi putusan Mahkamah Konstitusi menyatakan bahwa warga negara yang belum terdaftar di DPT dapat menggunakan Kartu Tanda Penduduk untuk melakukan pemilihan.

Janpatar Simamora dalam artikelnya Perlindungan Hak Memilih Sebagai Hak Konstitusional Warga Negara, ${ }^{3}$ menjelaskan bahwa putusan Mahkamah Konstitusi telah memberikan jaminan dan perlindungan bagi hak pilih warga negara. Putusan ini berkontribusi bagi proses demokratiasi dan peningkatan kualitas demokrasi di Indonesia. Dengan keputusan itu pula, maka dengan sendirinya akan mengurangi angka golongan putih dalam setiap perhelatan pemilu.

Asri Wijayanti dalam artikelmya Perlindungan Pekerja Dalam Menggunakan Hak Pilih Dalam Pemilu 2019, ${ }^{4}$ menjelaskan bahwa perlindungan hukum bagi pekerja dalam menggunakan hak pilihnya telah dilindungi oleh UU 13/2003 jo. UU 7/2017. Di mana pekerja berhak untuk tidak bekerja pada hari pemilihan karena merupakan hari libur nasional. Pekerja dapat bekerja pada hari pemilihan dengan tetap mendapatkan hak untuk memilih pada saat waktu kerja dengan mengikuti ketentuan pemberian upah lembur.

Sementara itu, Yunita Sakbani menjelaskan tentang Urgensi Manajemen Risiko Pemilu Pada Pilkada 2020 di Tengah Pandemi Covid 19: Studi Perlindungan Hak Pilih Warga Masyarakat. ${ }^{5}$ Menurutnya manajemen risiko pemilu perlu untuk menjamin seluruh warga negara agar dapat berpartisipasi baik sebagai pemilih maupun kandidat dengan tujuan memilih dan menentukan wakil politik mereka. Oleh karena itu, dengan manajemen risiko maka berbagai potensi risiko yang akan terjadi pada Pilkada dapat di identifikasi, dianalisis dan diputuskan.

${ }^{2}$ Himawan Estu Bagijo, "Daftar Pemilih Tetap dan Perlindungan Hak Pilih: Kajian PerundangUndangan Dan Keputusan Mahkamah Konstitusi" dalam Perspektif, Vol. 15, No. 4 (2010), h. 335-357.

${ }^{3}$ Janpatar Simamora, "Perlindungan Hak Memilih Sebagai Hak Konstitusional Warga Negara" dalam Jurnal Yudisial, Vol. 6, No. 2 (2013), h. 123 - 142.

${ }^{4}$ Asri Wijayanti, "Perlindungan Pekerja Dalam Menggunakan Hak Pilih Dalam Pemilu 2019" dalam Prosiding Seminar Nasional dan Call For Papes : Pemilu 2019 Momentum Penguatan Demokratisasi Indonesia yang Berintegritas (Ponorogo: Unmuh Ponorogo Press, 2018).

${ }^{5}$ Yunita Sakbani, "Urgensi Manajemen Risiko Pemilu Pada Pilkada 2020 di Tengah Pandemi Covid 19: Studi Perlindungan Hak Pilih Warga Masyarakat" dalam Jurnal Wacana Politik, Vol. 5, No. 2 (2020), h. $124-135$. 
Dari uraian kajian di atas dapat disimpulkan bahwa regulasi atau konstitusi telah memberikan perlindungan yang cukup bagi warga negara atas hak pilihnya. Apalagi Mahkamah Konstitusi telah memutuskan pembatalan pasal-pasal yang dianggap bertentangan dengan hak konstitusional warga negara untuk mendapatkan akses memilih pada saat pemilu diselenggarakan. Hal yang membedakan dari tulisan ini adalah bahwa artikel di atas belum secara memadai menjelaskan sejauhmana kinerja KPU selaku penyelenggara pemilu bekerja berdasarkan aturan yuridis yang telah ditetapkan dalam rangka perlindungan hak pilih warga negara. Kekurangan itu akan coba di isi dengan memfokuskan pada bagaimana kinerja KPU Kota Makassar selaku penyelenggara dapat menjamin atau memberikan perlindungan bagi hak pilih warga Makassar.

\section{Metode Penelitian}

Penelitian ini menggunakan tipe penelitian deskriptif dengan pendekatan kualitatif. Informan penelitian ini adalah Komisioner KPU Kota Makassar, Panitia Pemilihan Kecamatan, Panwas Kecamatan serta masyarakat di Kota Makassar. Jenis data yang digunakan adalah data yang berbentuk angka, tulisan dan data berbentuk katakata. Sumber data primer yang berasal dari wawancara terhadap informan dan sumber data sekunder berasal dari dokumen, buku, data statistik, laporan dan lain-lain. Adapun teknik pengumpulan data melalui observasi, wawancara, dokumentasi dan studi kepustakaan. Data yang diperoleh kemudian dianalisis dan diinterpretasi melalui reduksi data yang diperoleh dan disajikan yang pada akhirnya ditarik kesimpulan atas jawaban-jawaban yang diperoleh dari informan.

\section{Kinerja KPU Kota Makassar dalam Melindungi Hak Pilih Warga}

Dalam buku panduan IDEA, standar-standar internasional pemilu di mana salah satu standar yaitu kerangka hukum harus memastikan semua warga negara yang memenuhi syarat dijamin berhak memberikan suara secara universal dan adil serta berhak ikut dalam pemilihan tanpa diskriminasi. ${ }^{6}$ Sejalan dengan itu, kerangka hukum di Indonesia telah memastikan semua warga negara dapat memilih dengan syarat-syarat

${ }^{6}$ IDEA, Standar-Standar Internasional Untuk Pemilihan Umum. Pedoman Peninjauan Kembali Kerangka Hukum Pemilu (Swedia: International IDEA, 2002), h.35. 
tertentu yang ditetapkan oleh undang-undang. Menurut Undang-undang Nomor 7 Tahun 2017 tentang Pemilihan Umum, menegaskan bahwa syarat warga negara yang memiliki hak pilih sesuai pasal 198 ayat (1) dan (2) yaitu: (1) Warga negara Indonesia yang pada saat pemungutan suara sudah genap berumur 17 (tujuhbelas) tahun atau lebih, sudah kawin, atau sudah pernah kawin mempunyai hak memilih; (2) Warga negara Indonesia sebagaimana dimaksud ayat (1) didaftar 1 (satu) kali oleh Penyelenggara Pemilu dalam daftar Pemilih. Berdasarkan ketentuan tersebut maka warga negara secara konstitusional dilindungi serta dijamin dan tidak boleh dihambat atau dihalangi oleh berbagai ketentuan dan prosedur administratif apapun yang mempersulit warga negara untuk menggunakan hak pilihnya.

\section{Proses Pencocokan dan Penelitian di Kota Makassar}

Berdasarkan Peraturan Komisi Pemilihan Umum (PKPU) Nomor 5 Tahun 2020 tentang Perubahan Ketiga Atas Peraturan Komisi Pemilihan Umum Nomor 15 Tahun 2019 Tentang Tahapan, Program, dan Jadwal Penyelenggaraan Pemilihan Gubernur dan Wakil Gubernur, Bupati dan Wakil Bupati, dan/atau Wali Kota dan Wakil Wali Kota Tahun 2020, Panitia Pemutakhiran Data Pemilih (PPDP) bekerja pada 15 Juli 2020, dan berakhir 13 Agustus 2020. Tahapan pemutakhiran data pemilih yang dilakukan oleh Petugas Pemutakhiran Data (PPDP) adalah tahapan yang paling penting di mana PPDP melakukan proses pencocokan dan penelitian (coklit) dengan mendatangi rumah-rumah warga dan mencatat pemilih yang telah memenuhi syarat dengan cara: (a) mencatat Pemilih yang telah memenuhi syarat, tetapi belum terdaftar dalam Daftar Pemilih; (b) memperbaiki data Pemilih apabila terdapat kekeliruan; (c) mencatat keterangan Pemilih berkebutuhan khusus pada kolom jenis disabilitas; (d) mencoret Pemilih yang telah meninggal;(e) mencoret Pemilih yang telah pindah domisili ke daerah lain; (f) mencoret Pemilih yang telah berubah status dari status sipil menjadi status anggota Tentara Nasional Indonesia atau Kepolisian Negara Republik Indonesia; (g) mencoret Pemilih yang belum genap berumur 17 (tujuh belas) tahun dan belum kawin/menikah pada hari pemungutan suara; (h) mencoret data Pemilih yang telah dipastikan tidak diketahui keberadaannya; (i) mencoret data Pemilih yang tidak dikenal; (j) mencoret Pemilih yang sedang dicabut hak pilihnya berdasarkan putusan pengadilan yang telah berkekuatan hukum tetap; mencoret Pemilih, yang berdasarkan KTP-el atau Surat Keterangan bukan 
merupakan penduduk setempat; (k) dan mencoret Pemilih yang tidak sesuai antara informasi TPS awal yang ada pada formulir Model A-KPU untuk disesuaikan dengan TPS terdekat berdasarkan domisili alamat Pemilih dalam lingkup satu wilayah kelurahan/desa. PPDP mendatangi rumah kerumah untuk memastikan daftar pemilih akuntabel dan valid.

Proses coklit kali ini berbeda dengan pemilihan sebelumnya di mana pada pemilihan ini, masyarakat ditakutkan dengan COVID-19. Sehubungan dengan terjadinya pandemi, KPU Kota Makassar melakukan protokol kesehatan agar PPDP yang bertugas ke rumah warga tidak membuat kluster baru dalam proses coklit. PPDP yang turun untuk melakukan coklit data pemilih telah melakukan rapid test dan dinyatakan non-reaktif. Selain itu PPDP juga dilengkapi dengan alat protokol kesehatan seperti masker, face shield, sarung tangan, hand sanitizer, dan alat tulis pribadi. Proses coklit ini dilakukan di depan teras rumah warga dalam upaya untuk mencegah penularan COVID-19. ${ }^{7}$ PPDP wajib menjaga keselamatan dengan memakai Alat Pelindung Diri (APD) dan mengkonsumsi suplemen. Petugas PPDP juga diwajibkan mengikuti protokol kesehatan dengan mencuci tangan dan bersih-bersih diri setelah bertugas.

Pada saat melaksanakan coklit, PPDP menemukan hambatan di lapangan, untuk daerah yang tinggal di pusat kota, seperti Kecamatan Rappocini. Di mana ada beberapa warga yang sedang menjalani isolasi mandiri dan terdapat beberapa wilayah yang menerapkan lockdown karena wilayah tersebut masuk dalam zona merah. ${ }^{8}$ Selain itu, masyarakat terutama yang tinggal di perumahan elit cenderung agak tertutup sehingga tidak mau menerima kunjungan dari PPDP. Selain itu terdapat masyarakat yang tidak mau dicoklit kalau bukan dari pihak KPU Kota Makassar yang langsung turun melakukan coklit. ${ }^{9}$ Hambatan PPDP di mana masyarakat menolak untuk dicoklit akibat takut terpapar COVID-19 juga terjadi di Kecamatan Tamalanrea. ${ }^{10}$ Hambatan yang ditemukan di Kecamatan Kepulauan Sangkarrang berbeda dengan yang ditemukan di daerah daratan. Faktor geografis dan anggaran yang dialokasikan KPU cukup menghambat. Keadaan alam yang tidak mendukung membuat PPDP tidak bisa

\footnotetext{
${ }^{7}$ KPU Kota Makassar, "Petugas Pemutakhiran Data Pemilih (PPDP) Dipastikan Non-reaktif" dalam https://kota-makassar.kpu.go.id/web/3662/petugas-pemutakhiran-data-pemilih-ppdp-dipastikannon-reaktif/ diakses 1 Desember 2020.

${ }^{8}$ Harris, Panitia Pemilihan Kecamatan Rappocini, wawancara, 2 Desember 2020.

${ }^{9}$ Rere, Panwas Pemilihan Kecamatan Rappocini, wawancara, 30 November 2020.

${ }^{10}$ Heru, Panitia Pemilihan Kecamatan Tamalanrea, wawancara, 2 Desember 2020.
} 
melaksanakan coklit sesuai rencana. Anggaran transportasi yang diberikan juga tidak cukup untuk mereka melaksanakan kegiatan terutama dikepulauan terluar Kecamatan Sanggkarang. Namun, untuk suksesnya pelaksanaan Pilwalkot 2020, PPK memberikan uang pribadinya agar kegiatan ini tetap terlaksana. Selain itu, disalah satu pulau juga ada masyarakat yang tidak mau didata akibat konflik antara pemerintah dan masyarakat. Namun, PPK tetap memberikan pemahaman bahwa pentingnya mereka didata agar mereka bisa memberikan hak suaranya untuk perubahan besar di Kota Makassar. ${ }^{11}$

Dalam melaksanakan tugasnya, PPDP diberikan standar operasional prosedur, selain wajib melaksanakan protokol kesehatan, juga wajib melakukan kunjungan kembali ke rumah warga yang tidak berhasil dicoklit pada saat kunjungan pertama. PPDP wajib kembali ke rumah warga sebanyak 3 (tiga) kali kunjungan. Selain itu PPDP juga telah diberikan bimbingan teknis terkait tugas mereka di lapangan. ${ }^{12}$

Pendaftaran warga negara untuk ikut serta dalam Pemilu dan Pilkada di kota Makassar mengalami penurunan, terdapat beberapa kecamatan mengalami penurunan namun adapula kecamatan mengalami kenaikan. Adapun perubahan jumlah Daftar Pemilih Tetap pada tahun 2018, 2019 dan 2020 dapat dilihat pada tabel berikut:

Tabel 1.

Selisih Jumlah Daftar Pemilih Tetap Pilwalkot 2018, Pemilu 2019 dan Pilwalkot 2019 per kecamatan di Kota Makassar

\begin{tabular}{|c|l|r|r|r|}
\hline \multirow{2}{*}{ NO } & \multirow{2}{*}{ Kecamatan } & \multicolumn{3}{|c|}{ Daftar Pemilih Tetap } \\
\cline { 3 - 5 } & & Pilwalkot 2018 & Pemilu 2019 & Pilwalkot 2020 \\
\hline 1 & Mariso & 39,574 & 37,296 & 37,194 \\
\hline 2 & Mamajang & 39,469 & 38,280 & 36,628 \\
\hline 3 & Makassar & 56,376 & 55,782 & 54,210 \\
\hline 4 & Ujung Pandang & 20,715 & 20,332 & 18,430 \\
\hline 5 & Wajo & 22,061 & 21,304 & 20,424 \\
\hline 6 & Bontoala & 38,412 & 38,306 & 36,261 \\
\hline 7 & Tallo & 93,566 & 93,009 & 89,791 \\
\hline 8 & Ujung Tanah & 24,249 & 23,653 & 22,491 \\
\hline
\end{tabular}

\footnotetext{
${ }^{11}$ As'ad, Panitia Pemilihan Kecamatan Kepulauan Sangkarrang, wawancara 2 Desember 2020.

${ }^{12}$ Romy Harminto, Komisioner Divisi Perencanaan dan Data, wawancara, 30 November 2020.
} 


\begin{tabular}{|r|l|r|r|r|}
\hline 9 & Panakukang & 114,566 & 115,488 & 88,939 \\
\hline 10 & Tamalate & 145,718 & 138,311 & 108,671 \\
\hline 11 & Biringkanaya & 124,125 & 119,817 & 123,226 \\
\hline 12 & Manggala & 90,809 & 87,246 & 95,316 \\
\hline 13 & Rappocini & 102,571 & 103,825 & 98,121 \\
\hline 14 & Tamalanrea & 68,026 & 65,036 & 61,881 \\
\hline 15 & $\begin{array}{l}\text { Kepulauan } \\
\text { Sangkarrang }\end{array}$ & 10,599 & 9,905 & 9,504 \\
\hline & J u m l a h & 990,836 & 967,590 & 901,087 \\
\hline
\end{tabular}

Sumber: KPU Kota Makassar

Berdasarkan tabel di atas, hanya 2 kecamatan yang mengalami kenaikan jumlah pemilih pad Pemilu 2019 dibandingkan Pilwalkot 2018 yaitu Kecamatan Rappocini dan Kecamatan Panakukkang. Sedangkan 13 kecamatan yang lain mengalami penurunan. Dan hanya 2 kecamatan yang mengalami kenaikan jumlah pemilih di Pilwalkot 2020 dibandingkan Pemilu 2019 yaitu Kecamatan Biringkanaya dan Kecamatan Manggala. Sedangkan 13 kecamatan yang lain mengalami penurunan.

Proses Pemutakhiran Data yang dilakukan di Kota Makassar pada Pilwalkot 2020 dibandingkan dengan Pilwalkot 2018 sudah semakin membaik. PPDP telah melaksanakan tugasnya dengan baik, menurunnya jumlah wajib pilih karena banyak masyarakat yang tidak berada di rumah. ${ }^{13}$ Makassar juga merupakan kota urban sehingga banyak pekerja dari luar Makassar. Perusahaan-perusahaan swasta yang berada di Makassar mewajibkan pekerjanya ber KTP-el Makassar. Akibat pandemi, banyak perusahaan yang melakukan PHK. Sehingga pada saat coklit, PPDP tidak dapat temui pekerja tersebut karena telah pulang kampung. Pada proses coklit, apabila PPDP tidak menemukan pemilih setelah melakukan kunjungan 3 kali, setelah itu PPDP juga berusaha mencari tahu ke tetangga maupun ke RT berkaitan warga yang tidak dapat mereka kunjungi. Apabila informasi yang mereka dapatkan apakah warga tersebut memang tidak ada maka pemilih tersebut di masukkan dengan kode tidak masuk syarat

\footnotetext{
${ }^{13}$ Reza, Panitia Pemilihan Kecamatan Tamalanrea, wawancara 2 Desember 2020.
} 
(TMS) dalam daftar pemilih. Hal ini dilakukan agar tidak terjadi penyalahgunaan hak pilih pada saat pemungutan suara. ${ }^{14}$

Proses-proses sosialisasi juga telah maksimal dilakukan, selain sosialisasi konvensional seperti pengumuman melalui tempat ibadah, PPS juga melakukan sosialisasi yang cukup massif melalu sosial media terutama melalui Instagram dan Facebook pada akun masing-masing PPS di setiap kelurahan sekecamatan Rappocini. Di setiap kegiatan sosialisasi, PPK selalu menginfokan ke warga peserta sosialisasi untuk mengecek nama dan TPS mereka di DPT. Adapun untuk yang belum terdaftar di wilayah tersebut, akan difasilitasi oleh PPS untuk masuk dalam DPTb. ${ }^{15}$ Selain itu sosialisasi ke masyarakat di wilayah kepulauan Makassar juga dilaksanakan. Menurut Endang Sari, Komisioner Divisi Sosialisasi, Pendidikan Pemilih, SDM dan Partisipasi Masyarakat program KPU Goes to Island ini bertujuan untuk lebih dekat dengan warga di wilayah pulau sehingga bisa mendengar apa yang menjadi kendala terkait tahapan Pilkada, khususnya Pilwalkot Makassar 2020. Dalam sosialisasi itu, disampaikan pula terkait pencocokan dan penelitian data pemilih yang dilakukan PPDP. Agar tidak ada lagi warga yang tidak terdaftar pada pemilihan, untuk itu warga juga harus proaktif melapor jika rumahnya belum didatangi guna memperjuangkan hak pilihnya. ${ }^{16}$

Sosialisasi di wilayah Kecamatan Kepulauan Sangkarrang juga maksimal dilakukan oleh PPK dan PPS dengan mendatangi warga, hal ini dilakukan karena wilayah tersebut memiliki jaringan komunikasi yang buruk. ${ }^{17}$ Proses sosialisasi ini harus terus diupayakan oleh KPU Kota Makassar karena masih banyak warga yang belum mengetahui bagaimana cara mereka mengecek apakah mereka sudah terdaftar atau tidak tanpa harus keluar rumah. Selain itu, materi sosialisasi yang harus terus dilakukan selain hak pilih juga bagaimana memberikan kepercayaan kepada masyarakat agar mau ke TPS karena di TPS sekarang berbeda dengan pemilihan sebelumnya, di mana pada pemilihan sekarang, jumlah pemilih dikurangi, jadwal untuk memilih telah ditentukan dan yang paling utama tetap menjaga protokol kesehatan seperti sebelum

\footnotetext{
${ }^{14}$ Romy Harminto, Komisioner Divisi Perencanaan dan Data, wawancara, 30 November 2020.

${ }^{15}$ Harris, Panitia Pemilihan Kecamatan Rappocini, wawancara, 2 Desember 2020.

${ }^{16}$ Lukman Zainuddin, "KPU Ajak Warga Kepulauan di Makassar Salurkan Hak Pilih di Pilkada 2020” dalam https://makassar.sindonews.com/read/127562/710/kpu-ajak-warga-kepulauan-di-makassarsalurkan-hak-pilih-di-pilkada-2020-1596938934 diakses 2 Desember 2020

${ }^{17}$ As'ad. Panitia Pemilihan Kecamatan Kepulauan Sangkarrang, wawancara, 2 Desember 2020.
} 
masuk ke TPS harus mencuci tangan dan di TPS telah disediakan tempat cuci tangan, pemeriksa suhu dan kaos tangan pemilih ${ }^{18}$

Peraturan Komisi Pemilihan Umum Nomor 18 Tahun 2020 Tentang Perubahan atas Peraturan Komisi Pemilihan Umum Nomor 8 Tahun 2018 Tentang Pemungutan dan Penghitungan Suara Gubernur dan Wakil Gubernur, Bupati dan Wakil Bupati dan/atau Walikota dan Wakil Walikota pada Pasal 9 menyatakan bahwa pemilih yang tidak terdaftar dalam DPT masih bisa menggunakan hak pilihnya dengan menunjukkan KTP-el atau surat keterangan kepada KPPS pada saat pemungutan suara dan akan didaftar pada DPTb. Untuk melindungi hak konstitusional warga negara, KPU fokus kepada pemilih yang belum rekam KTP-el. Berdasarkan dari data KPU bahwa terdapat \pm 31.800 orang yang belum melakukan perekaman KTP-el, oleh karena itu KPU Kota Makassar bekerjasama dengan Dinas Kependudukan dan Catatan Sipil mengupayakan agar warga Makassar yang belum melakukan perekaman KTP-el agar segera melakukan perekaman dengan menyurati warga tersebut hingga tersisa \pm 3.000 yang belum melakukan perekaman, namun warga yang belum melakukan perekaman tersebut setelah menerima by name KPU beserta Disdukcapil tetap mengupayakan menghubungi warga tersebut agar melakukan perekaman KTP-el. Untuk kemudahan yang diberikan kepada masyarakat, proses perekaman KTP-el ini juga dilakukan di kecamatan selain di kantor Dinas Kependudukan dan Catatan Sipil. Proses perekaman ini ditargetkan 0\% warga yang tidak melakukan perekaman sebelum hari pemungutan suara ${ }^{19}$.

Proses pemutakhiran data pemilih terdapat 7 prinsip yaitu akurat, komprehensif, mutakhir, inklusif, responsif dan partisipatif, dalam penetapan daftar pemilih dilakukan rekap berjenjang secara terbuka, partisipatif dan transparan. Sebelum penetapan Daftar Pemilih Tetap, KPU melakukan uji publik, audit internal dan koordinasi dengan berbagai pihak seperti Badan Pengawas Pemilu, Dinas Kependudukan dan Catatan Sipil, Pasangan Calon serta Pemerintah Desa/Kelurahan agar data yang dihasilkan akuntabel dan valid. Pada proses keterbukaan informasi, KPU melindungi data pribadi pemilih dengan mengumumkan atau memberikan salinan data pemilih dengan mengganti 8 angka terakhir pada Nomor Induk Kependudukan dan Nomor Kartu Keluarga (NKK) agar data pribadi pemilih tidak dapat disalahgunakan.

\footnotetext{
${ }^{18}$ Himar, warga kecamatan Tamalanrea. Wawancara, 2 Desember 2020

${ }^{19}$ Romy Harminto, Komisioner Divisi Perencanaan dan Data, wawancara, 30 November 2020.
} 


\section{Kesimpulan}

Perlindungan hak pilih wajib menjadi perhatian khusus karena dalam UUD 1945 telah sangat jelas bagaimana konstitusi telah melindungi warganya terkait hak pilih maupun hak memilih. KPU sebagai lembaga yang memiliki tanggung jawab terhadap perlindungan hak pilih warga negara maupun hak dipilih agar melaksanakan tanggung jawabnya dengan baik.

Salah satu tahapan krusial untung melindungi hak pilih warga terutama di masa pandemi yaitu proses pemutakhiran data pemilih. Pada tahapan proses pemutakhiran data pemilih, KPU Kota Makassar telah melaksanakan tugasnya dengan berpedoman pada regulasi yang ada. Selain itu, kerjasama dengan pemerintah terus dilakukan yang berkaitan dengan perekaman KTP-el sehingga target perekaman warga yang belum memiliki KTP-el dapat tercapai. KPU Kota Makassar beserta PPK dan PPS tetap berbenah agar warga yang belum terdaftar dalam DPT dapat memiliki hak pilih dengan didaftar pada DPTb. Sosialisasi telah diakukan baik melalui media sosial maupun bentuk konvensional lainnya seperti tatap muka, melalui spanduk maupun bentuk lainnya. Proses sosialisasi ini harus terus diupayakan oleh KPU Kota Makassar karena masih banyak warga yang belum mengetahui bagaimana cara mereka mengecek apakah mereka sudah terdaftar atau tidak tanpa harus keluar rumah.

Proses perlindungan hak pilih ini bukan hanya menjadi tanggung jawab KPU, masyarakat juga diperlukan pro-aktif untuk melindungi haknya dengan cara mengecek namanya di kantor desa/kelurahan tempat domisili mereka atau melalui website lindungihakpilihmu.kpu.go.id apakah sudah terdaftar atau tidak. Selain itu, pemerintah juga harus terus melakukan upaya agar data kependudukan di Indonesia tidak selalu menjadi masalah terutama pada saat pemilihan.

\section{DAFTAR PUSTAKA}

Bagijo, Himawan Estu. "Daftar Pemilih Tetap dan Perlindungan Hak Pilih: Kajian Perundang-Undangan Dan Keputusan Mahkamah Konstitusi" dalam Perspektif, Vol. 15, No. 4 (2010), h. 335-357.

Cerdas, Felani Ahmad \& Hernadi Afandi. "Jaminan Perlindungan Hak Pilih dan Kewajiban Negara Melindungi Hak Pilih Warga Negara dalam Konstitusi: Kajian Kritis Pemilu Serentak 2019” dalam SASI, Vol. 25, No. 1 (2019), h. 7283. 
IDEA. Standar-Standar Internasional Untuk Pemilihan Umum. Pedoman Peninjauan Kembali Kerangka Hukum Pemilu. Swedia: International IDEA, 2002.

Sakbani, Yunita. "Urgensi Manajemen Risiko Pemilu Pada Pilkada 2020 di Tengah Pandemi Covid 19: Studi Perlindungan Hak Pilih Warga Masyarakat" dalam Jurnal Wacana Politik, Vol. 5, No. 2 (2020), h. 124 - 135.

Simamora, Janpatar. "Perlindungan Hak Memilih Sebagai Hak Konstitusional Warga Negara" dalam Jurnal Yudisial, Vol. 6, No. 2 (2013), h. 123 - 142.

Wijayanti, Asri. "Perlindungan Pekerja Dalam Menggunakan Hak Pilih Dalam Pemilu 2019" dalam Prosiding Seminar Nasional dan Call For Papes : Pemilu 2019 Momentum Penguatan Demokratisasi Indonesia yang Berintegritas. Ponorogo: Unmuh Ponorogo Press, 2018.

\section{Website}

KPU Kota Makassar. "Petugas Pemutakhiran Data Pemilih (PPDP) Dipastikan Nonreaktif" dalam https://kota-makassar.kpu.go.id/web/3662/petugas-pemutakhirandata-pemilih-ppdp-dipastikan-non-reaktif/ diakses 1 Desember 2020.

Zainuddin, Lukman. "KPU Ajak Warga Kepulauan di Makassar Salurkan Hak Pilih di Pilkada 2020" dalam https://makassar.sindonews.com/read/127562/710/kpuajak-warga-kepulauan-di-makassar-salurkan-hak-pilih-di-pilkada-20201596938934 diakses 2 Desember 2020.

\section{Wawancara}

As'ad, Panitia Pemilihan Kecamatan Kepulauan Sangkarrang, wawancara 2 Desember 2020.

Harris, Panitia Pemilihan Kecamatan Rappocini, wawancara, 2 Desember 2020.

Heru, Panitia Pemilihan Kecamatan Tamalanrea, wawancara, 2 Desember 2020.

Himar, warga kecamatan Tamalanrea. Wawancara, 2 Desember 2020

Rere, Panwas Pemilihan Kecamatan Rappocini, wawancara, 30 November 2020.

Reza, Panitia Pemilihan Kecamatan Tamalanrea, wawancara 2 Desember 2020.

Romy Harminto, Komisioner Divisi Perencanaan dan Data, wawancara, 30 November 2020. 